\title{
Special issue "The 2015 Gorkha, Nepal, earthquake and Himalayan studies: First results"
}

\author{
Hiroe Miyake ${ }^{1 *}$, Soma Nath Sapkota ${ }^{2}$, Bishal Nath Upreti ${ }^{3,4}$, Laurent Bollinger ${ }^{5}$, Tomokazu Kobayashi ${ }^{6}$ \\ and Hiroshi Takenaka ${ }^{7}$
}

A devastating earthquake with a moment magnitude of 7.9 struck Nepal on 25 April 2015, resulting in nearly 9000 fatalities. This earthquake, called the 2015 Gorkha earthquake, was followed by large aftershocks to the west and east of the mainshock rupture. The mainshock propagated toward the east, and a large slip occurred beneath the capital city of Kathmandu. Contrary to the huge seismic moment release, the seismic intensity was not as large as expected, except for long-period slip pulses and basin resonance. This earthquake is seismologically remarkable in that the interplate earthquake occurred just below the inland area, which offers an invaluable opportunity to deepen our understanding of earthquakes in the collision zone and disasters related to them. This special issue focuses on multidisciplinary geoscientific research regarding the 2015 Gorkha earthquake and the relevant tectonics along the India-Eurasia plate collision zone.

The special issue includes 17 papers demonstrating the prompt analyses of the 2015 Gorkha earthquake as well as Himalayan studies conducted prior to the earthquake. Overall, the research led to the improved understanding of the 2015 Gorkha earthquake and Himalayan studies.

The unique tectonic setting of the Himalayan region has prompted extensive international scientific research. Consequently, many Himalayan studies had been conducted before the 2015 Gorkha earthquake. Bollinger et al. (2016) revealed the slip deficit and interpreted the repeatability of historical earthquakes. Sapkota et al. (2016) discussed the fatality rates of the 1934 BiharNepal earthquake. Sakai et al. (2016) clarified the geological features of the Paleo-Kathmandu lake. Bhattarai et al. (2016) observed ground motions before the 2015

\footnotetext{
*Correspondence: hiroe@eri.u-tokyo.ac.jp

${ }^{1}$ The University of Tokyo, Tokyo, Japan

Full list of author information is available at the end of the article
}

Gorkha earthquake and estimated the site response in and around the Kathmandu valley.

Unique interferometric synthetic aperture radar (InSAR) images and strong ground motion were recorded during the 2015 Gorkha earthquake; high-rate Global Navigation Satellite System (GNSS) observations were also made. The detailed ground surface changes and fault model are presented with InSAR images of ALOS-2 satellite. Natsuaki et al. (2016) performed InSAR analysis and reported some technical problems and the solutions. Kobayashi et al. (2015) revealed the geodetic slip distribution of the 2015 Gorkha earthquake using ScanSARbased interferograms and identified the remaining slip region with Mw 7.0 between the mainshock and the largest aftershock. Based on satellite images, Sato and Une (2016) and Lacroix (2016) detected earthquake-induced landslide in the Kathmandu and Langtang valleys, respectively.

Field survey was conducted to the east of the epicentral area around the Kathmandu valley. Although the earthquake magnitude was large, no surface fault was associated with the event (Kumahara et al. 2016). The earthquake survey was not limited from the land and toward the space field. Chum et al. (2016) captured the ionospheric signatures of the 2015 Gorkha earthquake.

With respect to strong motion data, Takai et al. (2016) observed clear differences in the ground motions between the rock and sediment sites in the Kathmandu valley. The rock site ground motion can be used to constrain the source characteristics. The nonlinear soil behavior at the sediment site was investigated by Dhakal et al. (2016). Yamada et al. (2016) performed a building damage survey and carried out microtremor observations in the source region of the 2015 Gorkha earthquake. Kobayashi et al. (2016) and Kubo et al. (2016) performed joint source inversion to estimate the rupture process of the 2015 Gorkha earthquake using various sets of observational data. Ichiyanagi et al. (2016) analyzed the 
aftershock activity of the 2015 Gorkha earthquake based on the local ground motion array. A statistical seismicity monitoring study on the 2015 Gorkha earthquake and aftershock sequence was performed by Ogata and Tsuruoka (2016).

The special issue demonstrates the scientific importance of Himalayan studies. Geospatial observations that captured the earthquake sequence were highlighted. The 2015 Gorkha earthquake ruptured beneath the capital city Kathmandu where urban strong motion data were utilized. The geodetic, seismological, and geological interpretations indicate that the potential remains for earthquakes in the region between the 2015 Gorkha earthquake and the largest eastern aftershock and in the Main Frontal Thrust. Therefore, further research is needed regarding the Himalayan region, which has the world's fastest inland collision rate.

\section{Authors' contributions}

All authors read and approved the final manuscript.

\begin{abstract}
Author details
${ }^{1}$ The University of Tokyo, Tokyo, Japan. ${ }^{2}$ Department of Mines and Geology, Kathmandu, Nepal. ${ }^{3}$ Nepal Academy of Science and Technology, Khumaltar, Kathmandu, Nepal. ${ }^{4}$ Department of Geology, School of Mines, University of Zambia, Lusaka, Zambia. ${ }^{5}$ CEA, Arpajon, France. ${ }^{6}$ Geospatial Information Authority of Japan, Tsukuba, Ibaraki, Japan. ${ }^{7}$ Okayama University, Okayama, Japan.
\end{abstract}

Received: 27 December 2016 Accepted: 27 December 2016

Published online: 06 January 2017

\section{References}

Bhattarai M, Adhikari LB, Gautam UP, Bollinger L, Hernandez B, Yokoi T, Hayashida T (2016) Establishing a reference rock site for the site effect study in and around the Kathmandu valley, Nepal. Earth Planets Space 68:81. doi:10.1186/s40623-016-0454-9

Bollinger L, Tapponnier P, Sapkota SN, Klinger Y (2016) Slip deficit in central Nepal: Omen for a repeat of the 1344 AD earthquake? Earth Planets Space 68:12. doi:10.1186/s40623-016-0389-1

Chum J, Liu J-Y, Laštovička J, Fišer J, Mošna Z, Baše J, Sun Y-Y (2016) lonospheric signatures of the April 25, 2015 Nepal earthquake and the relative role of compression and advection for Doppler sounding of infrasound in the ionosphere. Earth Planets Space 68:24. doi:10.1186/s40623-016-0401-9
Dhakal YP, Kubo H, Suzuki W, Kunugi T, Aoi S, Fujiwara H (2016) Analysis of strong ground motions and site effects at Kantipath, Kathmandu, from 2015 Mw 7.8 Gorkha, Nepal, earthquake and its aftershocks. Earth Planets Space 68:58. doi:10.1186/s40623-016-0432-2

Ichiyanagi M, Takai N, Shigefuji M, Bijukchhen S, Sasatani T, Rajaure S, Dhital MR, Takahashi H (2016) Aftershock activity of the 2015 Gorkha, Nepal, earthquake determined using the Kathmandu strong motion seismographic array. Earth Planets Space 68:25. doi:10.1186/s40623-016-0402-8

Kobayashi T, Morishita Y, Yarai H (2015) Detailed crustal deformation and fault rupture of the 2015 Gorkha earthquake, Nepal, revealed from ScanSARbased interferograms of ALOS-2. Earth Planets Space 67:201. doi:10.1186/ s40623-015-0359-z

Kobayashi H, Koketsu K, Miyake H, Takai N, Shigefuji M, Bhattarai M, Sapkota SN (2016) Joint inversion of teleseismic, geodetic, and near-field waveform datasets for rupture process of the 2015 Gorkha, Nepal, earthquake. Earth Planets Space 68:66. doi:10.1186/s40623-016-0441-1

Kubo H, Dhakal YP, Suzuki W, Kunugi T, Aoi S, Fujiwara H (2016) Estimation of the source process of the 2015 Gorkha, Nepal, earthquake and simulation of long-period ground motions in the Kathmandu basin using a one-dimensional basin structure model. Earth Planets Space 68:16. doi:10.1186/s40623-016-0393-5

Kumahara Y, Chamlagain D, Upreti BN (2016) Geomorphic features of active faults around the Kathmandu Valley, Nepal, and no evidence of surface rupture associated with the 2015 Gorkha earthquake along the faults. Earth Planets Space 68:53. doi:10.1186/s40623-016-0429-x

Lacroix P (2016) Landslides triggered by the Gorkha earthquake in the Langtang valley, volumes and initiation processes. Earth Planets Space 68:46. doi:10.1186/s40623-016-0423-3

Natsuaki R, Nagai H, Motohka T, Ohki M, Watanabe M, Thapa RB, Tadono T, Shimada M, Suzuki S (2016) SAR interferometry using ALOS-2 PALSAR-2 data for the Mw 7.8 Gorkha, Nepal earthquake. Earth Planets Space 68:15. doi:10.1186/s40623-016-0394-4

Ogata Y, Tsuruoka H (2016) Statistical monitoring of aftershock sequences: a case study of the 2015 Mw7.8 Gorkha, Nepal, earthquake. Earth Planets Space 68:44. doi:10.1186/s40623-016-0410-8

Sakai H, Fujii R, Sugimoto M, Setoguchi R, Paudel MR (2016) Two times lowering of lake water at around 48 and $38 \mathrm{ka}$, caused by possible earthquakes, recorded in the Paleo-Kathmandu lake, central Nepal Himalaya. Earth Planets Space 68:122. doi:10.1186/s40623-016-0413-5

Sapkota SN, Bollinger L, Perrier F (2016) Fatality rates of the Mw 8.2, 1934, Bihar-Nepal earthquake and comparison with the April 2015 Gorkha earthquake. Earth Planets Space 68:40. doi:10.1186/s40623-016-0416-2

Sato HP, Une H (2016) Detection of the 2015 Gorkha earthquake-induced landslide surface deformation in Kathmandu using InSAR images from PALSAR-2 data. Earth Planets Space 68:47. doi:10.1186/s40623-016-0425-1

Takai N, Shigefuji M, Rajaure S, Bijukchhen S, Ichiyanagi M, Dhital MR, Sasatani $\mathrm{T}$ (2016) Strong ground motion in the Kathmandu Valley during the 2015 Gorkha, Nepal, earthquake. Earth Planets Space 68:10. doi:10.1186/ s40623-016-0383-7

Yamada M, Hayashida T, Mori J, Mooney WD (2016) Building damage survey and microtremor measurements for the source region of the 2015 Gorkha, Nepal, earthquake. Earth Planets Space 68:117. doi:10.1186/ s40623-016-0483-4 